\title{
7. Sinıf Sosyal Bilgiler Ders Kitabında Yer Alan Etkinliklerin Sorgulamaya Dayalı Öğretime Uygunluğunun Değerlendirilmesi
}

DOI: $10.26466 /$ opus.740607

\author{
Turan Kaçar*- Cengiz Taşkıran** \\ * Dr., Gazi Ortaokulu, Diyarbakır/Türkiye \\ E-Posta: : kacarturan21@gmail.com \\ ORCID: 0000-0001-8390-7262 \\ ** Dr. Öğr. Üyesi, Muş Alparslan Üniversitesi, Eğitim Fakültesi, Muş/Türkiye \\ E-Posta: cengiztaskiran1@gmail.com \\ ORCID: $\underline{0000-0002-3677-6316}$
}

\section{$\ddot{O} z$}

Bu çalışmanın amacı, Milli Ĕ̆itim Bakanlı̆̆ının ülkemizde 2019-2020 eğitim-öğretim yılında okuttu$\breve{g} u$ 7. sınıf sosyal bilgiler ders kitabında yer alan etkinliklerin Sorgulamaya Dayalı Öğretim (SDÖ) stratejisine uygunlukların değerlendirmektir. Literatür incelendiğinde sosyal bilgiler eğitiminde SDÖ'nün uygulanabileceğine dair pek fazla bir çalışmaya rastlanmamıştır. Ayrıca literatür incelendiğinde sosyal bilgiler ders kitaplarında yer alan etkinliklerin SDÖ'ye uygunluklarının değerlendirilmesine yönelik herhangi bir çalışmaya rastlanılmaması da bu çalışmaya duyulan ihtiyacı göstermektedir. Bu açıdan bu çalışmanın sosyal bilgiler eğitimi alanında özgün bir yer bulacă̆ı ve sosyal bilgiler ders kitaplarında SDÖ'ye yönelik etkinliklerin daha fazla hazırlanacağı düşünülmektedir. Bu çalışmada nitel araştırma yöntemlerinden olan doküman incelemesi tekniği kullanılmıştır. Bu doğrultuda Milli Eğitim Bakanlığının ülkemizde 2019-2020 eğitim-öğretim yılında okuttuğu 7. sinıf sosyal bilgiler ders kitabında yer alan 10 etkinlik Bostan Sarıoğlan, Can ve Gedik (2016) tarafindan geliştirilen Araştırma-Sorgulamaya Dayalı Etkinlik Ölçeğine göre değerlendirilmiştir. Bu çalışmada, verilerin analizinde betimsel analiz tekniği kullanılmıştır. Bu çalışmanın sonuçlarına göre; araştırma kapsamında incelenen etkinliklerin tamamı SDÖ'ye kısmen uygundur. Incelenen tüm etkinliklerde en çok araştırmaya odaklama aşamasına yer verilirken anlamayı paylaşma aşamasına ise hiç yer verilmemiştir. SDÖ'ye en uygun olan etkinlik G20 Ülkeleri etkinliği iken SDÖ'ye en az uygun olan etkinlik ise Türk İslam Medeniyetinde Yetişen Bilginler etkinliğidir.

Anahtar Kelimeler: Sosyal bilgiler, Sorgulamaya dayalı öğretim, Ders kitabı, Etkinlik 


\title{
The Evaluation of the Suitability of the Activities in the 7th Grade Social Studies Textbook for Inquiry-Based Teaching
}

\begin{abstract}
The aim of this study is to evaluate the relevance of the activities in the 7th grade social studies textbook taught by the Ministry of National Education in Turkey in the 2019-2020 academic year to the Inquiry-Based Teaching (IBT) strategy. When the literature is analyzed, there are not many studies on the implementation of IBT in social studies education. In addition, when the literature is examined, the fact that there is no study to evaluate the suitability of the activities in the social studies textbooks to the IBT also indicates the need for this study. In this respect, it is thought that this study will find a unique place in the field of social studies education and activities for IBT will be prepared more in social studies textbooks. In this study, document review technique, which is one of the qualitative research methods, was used. Accordingly, 10 activities in the 7 th grade social studies textbook that the Ministry of National Education taught in Turkey in the 2019-2020 academic year were evaluated according to the Research-Inquiry-Based Activity Scale developed by Bostan Sarıoğlan, Can and Gedik (2016). In this study, descriptive analysis technique was used to analyze the data. According to the results of this study; All of the activities examined within the scope of the research are partially in line with IBT. In all the activities examined, the focus of research was mostly included, while the stage of sharing understanding was not included at all. While the activity that is most suitable for the IBT is the G20 Countries activity, the least suitable activity for the IBT is the Scholars Raising in the Turkish-Islamic Civilization.
\end{abstract}

Keywords: Social studies, Inquiry-based teaching, Textbook, Activity 


\section{Giriş}

Gülersoy'a (2013) göre ders kitabı, derste kullanılan ve dersin geliştirilmesine esas oluşturan araçlardandır ayrıca ders kitabı belli bir dersin öğretimi için, belli bir sınıf düzeyindeki öğrencilere yönelik olarak hazırlanan, içeriği öğretim programına uygun olan, incelemesi yapılmış ve onaylanmış temel bir kaynaktır. Şahin'e (2004) göre 1900'lü yıllardan beri eğitim sorunlarının ele alındığı ortamlarda ilk akla gelen mesele, ders kitapları olmuştur ayrıca ders kitapları eğitim programlarının temel unsurlarından biri ve eğitim programı ile öğrenci arasındaki köprünün en önemli ayağıdır. Mentiş Taş'a (2007) göre öğretim programlarının içeriğinin öğrencilere aktarımında ders kitapları çok büyük bir role, Gök'e (2003) göre ders kitapları öğrenme-öğretme sürecini doğrudan etkileme gücüne sahiptir. Delice, Aydın ve Kardeş'e (2009) göre ise ders kitapları, öğretim programlarında belirtilen amaç ve kazanımlara uygun içeriğe sahip, öğretmenlere sınıf içi etkinlikleri gerçekleştirme noktasında yardımcı olan ve eğitim-öğretim ortamlarında yaygın olarak kullanılan yazılı öğretim araçlarındandır. Demirel ve Kıroğlu (2019) ders kitabını, bir eğitim programında yer alan hedef, içerik, öğretme-öğrenme süreci ile ölçme değerlendirme boyutlarına uygun olarak hazırlanan ve öğrenme amaçlı kullanılan basılı bir öğretim materyali olarak tanımlamaktadır. Bu açıdan gerek okul içinde gerekse de okul dışında sıklıkla kullanılan ders kitaplarının öğrenciler için önemli bir kaynak ve öğretim aracı olduğu söylenebilir. Bu amaçla ders kitaplarında; yazılı materyaller, resimler, fotoğraflar, grafikler, tarih şeritleri, karikatürler, değerlendirmeler, etkinlikler ve haritalar bulunmaktadır. Gönen, Katrancı, Uygun ve Uçuş'a (2011) göre ilköğretim çağındaki çocukların okumaktan zevk alan bireyler olarak gelişmelerinde okumayı zevkli ve eğlenceli hale getirecek biçimde hazırlanmış kitapların rolü büyüktür.

Bu bağlamda öğrencilerin okumaktan zevk almaları ve eğlenerek öğrenmeleri için ders kitaplarında yer alan içeriklerde, öğretim sürecinde, etkinliklerde ve araştırmalarda yeni strateji, yöntem ve tekniklerin uygulanması oldukça önemlidir. Bu açıdan öğretim sürecinde uygulanabilecek yeni stratejilerden birinin de sosyal bilgiler eğitiminde pek fazla uygulanmayan Sorgulamaya Dayalı Öğretim (SDÖ) stratejisi olduğu ifade edilebilir. Güneş (2014) SDÖ'yü yapılandırmacı öğrenme yaklaşımı bün- 
yesinde yer alan stratejilerinden biri olarak, Hırça (2015) ise öğrencilerin sınıf içinde etkin bir rol üstlendiği, çevrelerindeki problemlerin farkında olduğu, bu problemlere yönelik farklı çözüm yolları ürettiği ve öğrenme sürecini daha etkili bir biçimde sürdürmesini sağlayan en etkili yollardan biri olarak değerlendirmektedir. Kartal (2014) da SDÖ'yü öğrencilerin gözlem yaptığı, sorular sorduğu, hipotez ve alternatifler belirlediği, bilgi topladığı, bilimsel yöntem ve teknikleri uyguladığı, değerlendirme, yorumlama ve analiz yaptığı bir etkinlik olarak belirtir. Bu açıklamalardan hareketle sosyal bilgiler ders kitaplarında yer alan etkinliklerin Bostan Sarığlan, Can ve Gedik'in (2016) geliştirdiği AraştırmaSorgulamaya Dayalı Etkinlik Ölçeği (ASDEÖ)'ne uygunluğunun değerlendirilmesinin önemi oldukça fazladır.

$\mathrm{Bu}$ açıklamalar doğrultusunda ders kitaplarında yer alan etkinliklerin önemi daha fazla ortaya çıkmaktadır. Türk Dil Kurumu Güncel Türkçe Sözlüğünde (2020) etkinliğin birçok tanımı yapılmıştır ancak etkinliğin eğitim ve öğretim açısından en uygun olan tanımı "Bir canlının iç veya dış uyaranların etkisiyle giriştiği çalışma durumu" olarak belirtilmektedir. Eğitim ve öğretim alanında etkinlik kavramı daha çok ders kitaplarında yer alan konuları, kazanımları, becerileri ve değerleri pekiştiren ve geliştiren ders içinde veya ders dişında yapılan faaliyetler olarak tanımlanabilir. Sosyal bilgiler dersinde bu faaliyetlerin, etkinliklerin bir kismında öğrenciler araştırma ve sorgulamaya sevk edilmektedir. Bu bağlamda sosyal bilgiler ders kitaplarında yer alan bazı etkinliklerde özellikle araştırma ve sorgulamaya yönelik faaliyetlere yer verilmesi öğrenme açısından oldukça faydalı olabilir.

Bu doğrultuda bu çalışmanın amac, Milli Eğitim Bakanlığının 20192020 eğitim-öğretim yılında ülkemizde okuttuğu 7. sınıf sosyal bilgiler ders kitabında yer alan etkinliklerin SDÖ'ye uygunluklarını belirlemektir. Literatür incelendiğinde sosyal bilgiler eğitiminde SDÖ'nün uygulanabileceğine dair çalışmalara (Çalışkan, 2008; Çalışkan, 2009; İlter, 2013; Letina, 2015; Jones, 2017; Bailey, 2018; Kaçar, 2020) az da olsa rastlanmıştır ancak sosyal bilgiler ders kitaplarında yer alan etkinliklerin SDÖ'ye uygunluklarının belirlenmesine yönelik herhangi bir çalışmaya rastlanılmaması da bu çalışmaya duyulan ihtiyacı göstermektedir. Bu açıdan bu çalışmanın sosyal bilgiler eğitimi alanında özgün bir yer bulacağı, literatürü güçlendireceği ve sosyal bilgiler ders kitaplarında SDÖ'ye 
yönelik etkinliklerin daha fazla hazırlanacağ lışmada Milli Eğitim Bakanlığının 2019-2020 eğitim-öğretim yılında ülkemizde okuttuğu 7. sınıf sosyal bilgiler ders kitabında yer alan etkinliklerin Bostan Sarıoğlan, Can ve Gedik'in (2016) geliştirdiği ASDEÖ’ye ne düzeyde uygun olduğu incelenmeye çalışılmıştır.

Bu amaç doğrultusunda bu çalışma kapsamında 7. sınıf sosyal bilgiler ders kitabındaki incelenen etkinliklerin SDÖ'ye uygunluklarının belirlenmesi için aşağıdaki sorulara yantlar aranmıştır:

1. Etkinlikler öğrencilerin ön bilgilerini ortaya çıkarmakta mıdır?

2. Etkinliklerde öğrencilere araştırabilecekleri sorular sorulmuş mudur?

3. Etkinliklerde öğrencilerin merak ettikleriyle öğretilmesi planlanan içerik arasında bir ilişki kurulmuş mudur?

4. Etkinlikler öğrencileri materyallerle etkileşime sevk etmekte midir?

5. Etkinlikler öğrencileri gözlem yapmaya sevk etmekte midir?

6. Etkinlikler öğrencileri olası açıklamalar yapmaya sevk etmekte midir?

7. Etkinlikler öğrencileri tahmin yapmaya ve yapılan tahminleri test etmeye yöneltmekte midir?

8. Etkinlikler öğrencileri sorular sormaya, sorulara tekrar döndürmeye ve yaptıkları gözlemler sonucunda açıklamalar yapmaya yöneltmekte midir?

9. Etkinlikler öğrencileri düşüncelerini, verilerini, bulgularını yazmaçizme gibi yöntemlerle kaydetmeye ve sunmaya yöneltmekte midir?

10. Etkinliklerde öğrencilere yaptıklarını, düşüncelerini toparlamak ve başkalarıyla nasıl paylaşacağını planlamaları hususunda belirli bir zaman verilmiş midir?

11. Etkinliklerde gruplara birbirlerinin fikirleri ile ilgili yorum yapma ve ek fikirler ortaya sunma için fırsat verilmiş midir?

12. Etkinliklerde öğretmene grupların verilerinden ve fikirlerinden yararlanarak ilgili konuyu özetleme için fırsat verilmiş midir?

\section{Yöntem}

Bu bölümde araştırmanın deseni, kapsamı, veri toplama aracı, verilerin toplanması ve verilerin analizine yönelik bilgilere yer verilmiştir. 


\section{Araştırma Deseni ve Kapsamı}

$\mathrm{Bu}$ çalışma nitel araştırma yöntemlerinden olan doküman incelemesi tekniği ile yürütülmüştür. Yıldırım ve Şimşek'e (2013) göre doküman incelemesi, araştırılması hedeflenen olgu veya olgular ile ilgili bilgileri içeren yazılı materyallerin analizini kapsayan bir tekniktir. Bu doğrultuda Milli Eğitim Bakanlığının ülkemizde 2019-2020 eğitim-öğretim yılında okuttuğu 7. sınıf sosyal bilgiler ders kitabında yer alan 10 etkinlik Bostan Sarıoglan, Can ve Gedik (2016) tarafından geliştirilen ASDEÖ'ye göre değerlendirilmiştir.

\section{Veri Toplama Aracı ve Verilerin Toplanması}

Literatür incelendiğinde veri toplama aracı olarak bu çalışma için uygun olduğu düşünülen Bostan Sarığlan, Can ve Gedik (2016) tarafından geliştirilen ASDEÖ belirlenmiştir. Bu amaçla öncelikle ASDEÖ'yü geliştiren araştırmacılardan (Bostan Sarıoğlan, Can ve Gedik, 2016) izin alınmıştır. Bu araştırmacıların geliştirdiği ASDEÖ üç bölümden (Sorgulamaya başlatma, Araştırmaya odaklama ve Anlamayı paylaşma) ve toplam 12 maddeden oluşmaktadır. Bu doğrultuda 7. sınıf sosyal bilgiler ders kitabında yer alan tüm etkinlikler (101 etkinlik) incelenmiştir. Ayrıca ünitelerde yer alan etkinliklerin oranına göre her ünitede en az bir etkinlik olmak üzere toplam 10 etkinlik incelemeye alınmıştır. Daha sonra incelemeye alınan etkinlikler ASDEÖ doğrultusunda iki araştırmacı tarafından ayrı ayrı kodlanarak doldurulmuştur.

\section{Verilerin Analizi}

Bu çalışmada, verilerin analizinde betimsel analiz tekniği kullanılmıştır. Yıldırım ve Şimşek'e (2008) göre betimsel analizde amaç, elde edilen bulguları düzenlenmiş ve yorumlanmış bir biçimde okuyucuya sunmaktır. Yıldırım ve Şimşek'e (2013) göre betimsel analizin çeşitli aşamaları vardır. Buna göre; betimsel analizin analiz için bir çerçeve oluşturma, tematik çerçeveye göre verilerin işlenmesi, bulguların tanımlanması ve bulguların yorumlanması gibi aşamaları vardır (Yıldırım ve Şimşek, 2013). 
Verilerin analizinde kodlayıcı güvenirliğinin sağlanması için ASDEÖ, araştırmacılar (İki kişi) tarafından kodlanmıştır. Her iki araştırmacı verileri ayrı ayrı kodlamasıyla Miles ve Huberman'ın (1994) belirlediği kodlayıcı güvenirliği hesaplanmıştır. Daha sonra iki araştırmacının kodladığ1 veriler Miles ve Huberman (2016) belirlediği formül (Görüş birliği sayıs1/toplam görüş birliği+görüş ayrılığı sayısı) doğrultusunda hesaplanarak çalışmanın güvenirlik düzeyi belirlenmiştir. Yapılan hesaplamalar doğrultusunda bu çalışmanın güvenirlik oranı $\% 91,6$ olarak belirlenmiştir. Bu tip nitel araştırmalarda güvenirliğin \%70'in üzerinde çıkması araştırmanın güvenilir olduğunu gösterir (Miles ve Huberman, 1994).

ASDEÖ üç bölümden (Sorgulamaya başlatma, Araştırmaya odaklama ve Anlamayı paylaşma) ve toplam 12 maddeden oluşmaktadır. Yapılan analizlerde ASDEÖ kapsaminda incelenen maddelere tam olarak uyulmuşsa 2, kısmen uyulmuşsa 1 ve uyulmamışsa sıfır (0) puan verilmiştir. Dolayısıyla her bir etkinliğin değerlendirilmesinde 12 madde olmasından dolayı her etkinlikte alınabilecek en fazla 24 en az ise sıfır (0) puandır. Ayrıca her etkinliğin değerlendirilmesinden alınan toplam puan 0-7 arasında ise etkinlik SDÖ'ye uygun değil, 8-15 arasında ise etkinlik SDÖ'ye kısmen uygun ve 16-24 arasında ise etkinlik SDÖ'ye uygundur.

\section{Bulgular}

Bu bölümde 7. Sınıf Sosyal Bilgiler ders kitabında yer alan etkinliklerin (10 tane) ASDEÖ'ye uygunluğuna yönelik bulgulara yer verilmiştir.

\section{İletişim ve İnsan İlişkileri Ünitesinde Yer Alan Genel Ă̆ Etkinliğine Yöne- lik Bulgular}

Bu bölümde İletişim ve İnsan İlişkileri Ünitesinde yer alan genel ağa (internet) yönelik etkinliğin ASDEÖ'ye uygunluğu belirlenmiştir. Bu etkinliğin ASDEÖ'ye uygunluğu aşamalar halinde Tablo 1'de verilmiştir.

Tablo 1. Genel Ă̆ (İnternet) Etkinliğinin ASDEÖ'ye Uygunluğu

\begin{tabular}{ll}
\hline ASDEÖ'nün Aşamaları & Alınan Puan \\
\hline 1. Sorgulamayı Başlatma Aşaması & 3 \\
\hline 2. Araştırmaya Odaklama Aşaması & 6 \\
\hline 3. Anlamayı Paylaşma Aşaması & 0 \\
\hline Etkinlikten Alınan Toplam Puan & $\mathbf{9}$ \\
\hline
\end{tabular}


Tablo 1'e göre genel ağ ile ilgili etkinliğin SDÖ'ye kısmen uygun olduğu söylenebilir. Zira bu etkinlik kapsamında ASDEÖ'den toplamda 24 puandan ancak 9 puan alınmıştır. Bu etkinlikte araştırmaya odaklama aşamasına en fazla yer verilirken anlamayı paylaşma aşamasına ise hiç yer verilmemiştir. Şekil 1'de genel ağ kullanımına yönelik etkinlik verilmiştir.

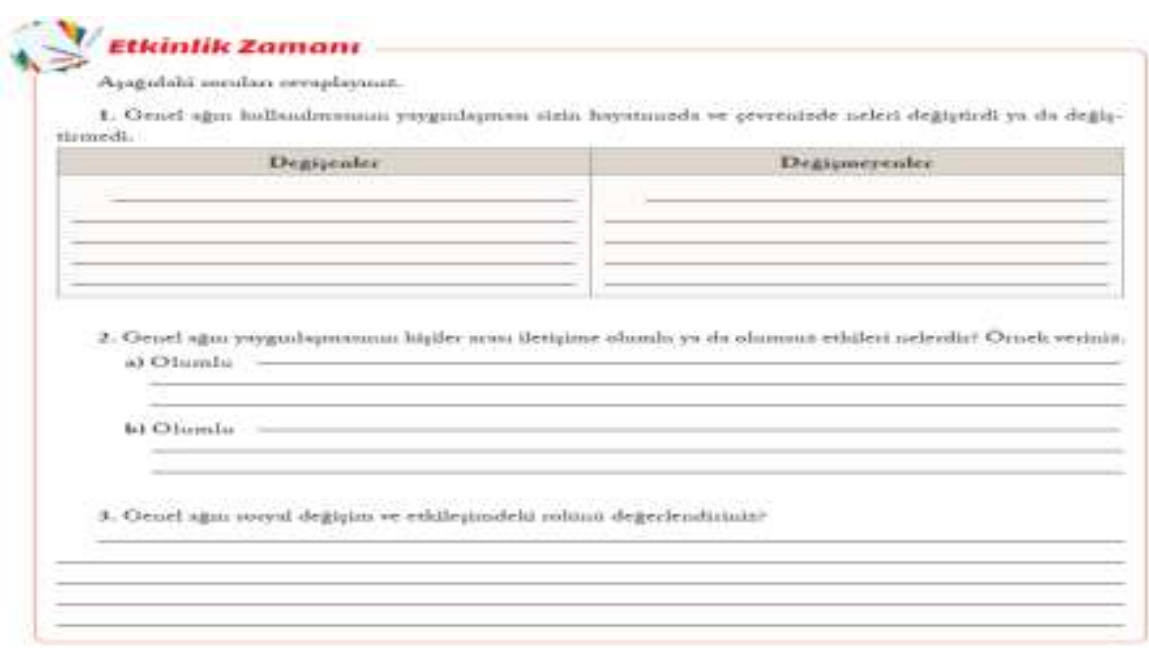

Şekil 1. Genel Ă̆ Kullanımına Yönelik Etkinlik

Şekil 1'deki genel ağa yönelik etkinlik incelendiğinde belirlenen etkinlikte öğrencilerin bir araştırmaya yöneltilmediği görülmüştür. Bu etkinlikte öğrencilere daha çok genel ağ ile ilgili görüşleri sorulmuştur. $\mathrm{Bu}$ etkinlikte öğrencilerden genel ağın kişiler arasında olumlu ve olumsuz etkilerine yönelik örnekler vermeleri istenmiş ve son olarak genel ağın sosyal değişim ve etkileşimdeki rolüne yönelik öğrencilerden bir değerlendirme yapmaları istenmiştir.

\section{Türk Tarihinde Yolculuk Ünitesinde Yer Alan Osmanl Devleti Döneminde Sanat Dallarn Etkinliğine Yönelik Bulgular}

Bu bölümde Türk Tarihinde Yolculuk Ünitesinde yer alan Osmanlı Devleti döneminde sanat dallarına yönelik etkinliğin ASDEÖ'ye uygunluğu ince- 
lenmiştir. Bu etkinliğin ASDEÖ'ye uygunluğu aşamalar halinde Tablo 2'de verilmiştir.

Tablo 2. Osmanlı Devleti Döneminde Sanat Dalları Etkinliğinin ASDEÖ'ye Uygunluğu

\begin{tabular}{ll}
\hline ASDEÖ'nün Aşamaları & Alınan Puan \\
\hline 1. Sorgulamayı Başlatma Aşaması & 4 \\
\hline 2. Araştırmaya Odaklama Aşaması & 6 \\
\hline 3. Anlamayı Paylaşma Aşaması & 0 \\
\hline Etkinlikten Alınan Toplam Puan & $\mathbf{1 0}$ \\
\hline
\end{tabular}

Tablo 2'ye göre Osmanlı Devleti döneminde sanat dallarına yönelik etkinliğin SDÖ’ye kısmen uygun olduğu söylenebilir. Zira bu etkinlik kapsamında ASDEÖ'den toplamda 24 puandan ancak 10 puan alınmıştır. Bu etkinlikte araştırmaya odaklama aşamasına en fazla yer verilirken anlamayı paylaşma aşamasına ise hiç yer verilmemiştir. Şekil 2'de Osmanlı Devleti döneminde sanat dallarına yönelik etkinlik verilmiştir.

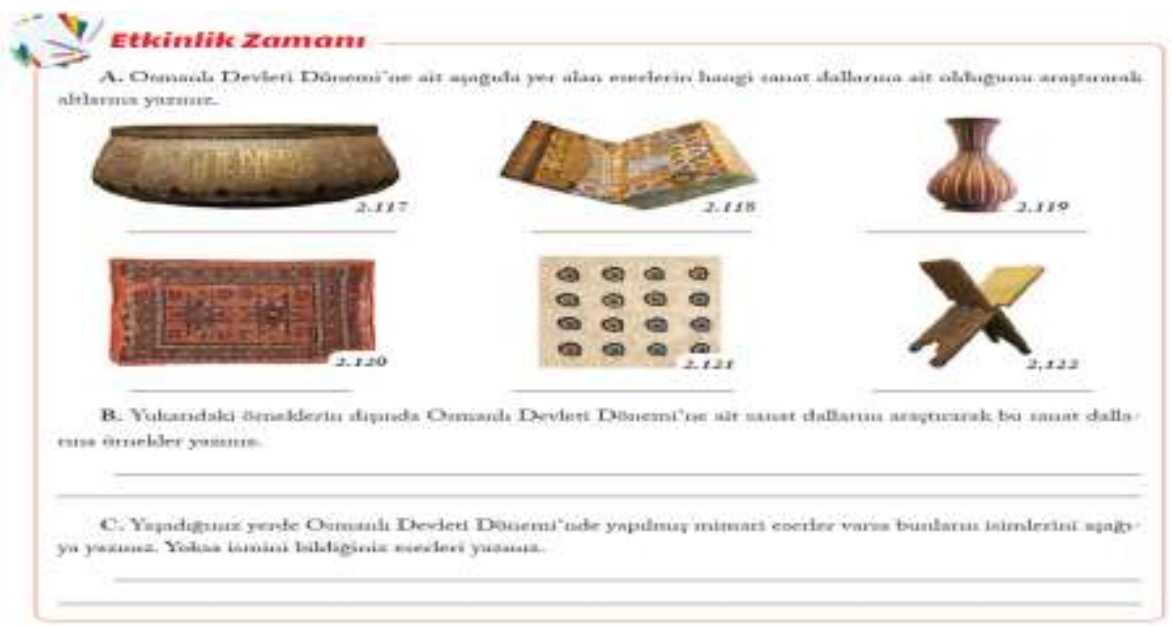

Şekil 2. Osmanlı Devletinin Sınırlarının Genişlemesine Yönelik Etkinlik

Şekil 2'de yer alan etkinlikte Osmanlı Devleti döneminde kullanılan bazı araç-gereçlerin hangi sanat dallarına ait olduğu ve Osmanlı Devleti dönemine ait başka sanat dallarının araştırılması istenmiştir. Son olarak öğrencilerin yaşadığı çevredeki Osmanlı Devleti döneminde yapılan mimari eserlere verecekleri örnekleri etkinlik kâğıdına yazmaları istenmiştir. 
Türk Tarihinde Yolculuk Ünitesinde Yer Alan Rönesans ve Aydınlanma Çă̆ı Etkinliğine Yönelik Bulgular

Bu bölümde Türk Tarihinde Yolculuk Ünitesinde yer alan Rönesans ve Aydınlanma Çağına yönelik etkinliğin ASDEÖ'ye uygunluğu incelenmiştir. Bu etkinliğin ASDEÖ'ye uygunluğu aşamalar halinde Tablo 3'te verilmiştir.

Tablo 3. Rönesans ve Aydınlanma Çă̆ı Etkinliğinin ASDEÖ'ye Uygunluğu

\begin{tabular}{ll}
\hline ASDEÖ'nün Aşamaları & Alınan Puan \\
\hline 1. Sorgulamayı Başlatma Aşaması & 4 \\
\hline 2. Araştırmaya Odaklama Aşaması & 5 \\
\hline 3. Anlamayı Paylaşma Aşaması & 0 \\
\hline Etkinlikten Alınan Toplam Puan & $\mathbf{9}$ \\
\hline
\end{tabular}

Tablo 3'e göre Rönesans ve Aydınlanma Çağı ile ilgili etkinliğin SDÖ'ye kısmen uygun olduğu söylenebilir. Zira bu etkinlik kapsamında ASDEÖ'den toplamda 24 puandan ancak 9 puan alınmıştır. Bu etkinlikte araştırmaya odaklama aşamasına en fazla yer verilirken anlamayı paylaşma aşamasına ise hiç yer verilmemiştir. Şekil 3'te Rönesans ve Aydınlanma Çağına yönelik etkinlik verilmiştir.

\section{Etkinlik Zamanı}

Röneeane ve Aydılanuma Çağı konulanında ieimleri geçen kiģilerden birinin hayatıu araçtırınz. Bu kiogiyle ilgili edindiğiniz bilgilerden yararlanarak ģemayı doldurunuz.

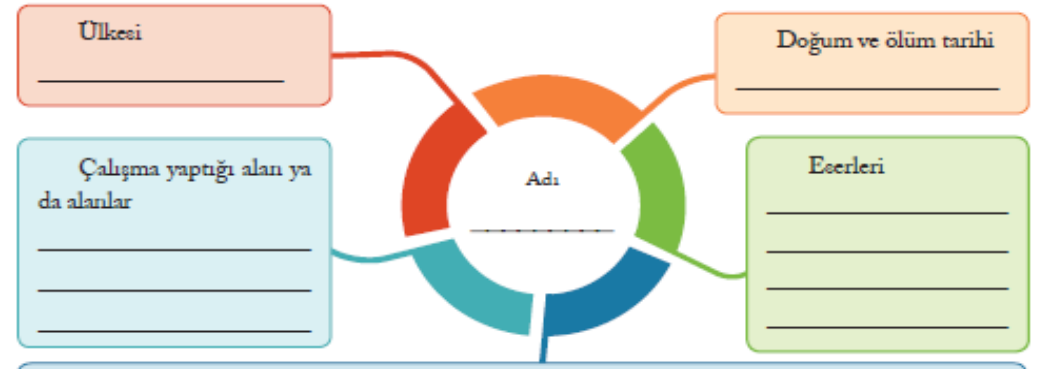

Bilim, eanat ya da düģünce haynatuna katkıı

Şekil 3. Rönesans ve Aydınlanma Çağına Yönelik Etkinlik 
Şekil 3'te yer alan Rönesans ve Aydınlanma Çağına yönelik etkinlik incelendiğinde öğrencilerden Rönesans ve Aydınlanma Çağı ile ilgili konulardan herhangi birinde ismi geçen şahıslardan birinin hayatının araştırılması istenmiştir. Bu etkinlikte öğrencilerden araştırdıkları kişilerle ilgili bazı bilgilerin etkinlik kâğıdı üzerinde doldurmaları istenmiştir.

Türk Tarihinde Yolculuk Ünitesinde Yer Alan Osmanlı Devletinde Fethedilen Yerler Etkinliğine Yönelik Bulgular

Bu bölümde Türk Tarihinde Yolculuk Ünitesinde yer alan Osmanlı Devletinde fethedilen yerlere yönelik etkinliğin ASDEÖ'ye uygunluğu incelenmiştir. Bu etkinliğin ASDEÖ'ye uygunluğu aşamalar halinde Tablo 4 'te verilmiştir.

Tablo 4. Osmanl Devletinde Fethedilen Yerler Etkinliğinin ASDEÖ'ye Uygunluğu

\begin{tabular}{ll}
\hline ASDEÖ'nün Aşamaları & Alınan Puan \\
\hline 1. Sorgulamayı Başlatma Aşaması & 5 \\
\hline 2. Araştırmaya Odaklama Aşaması & 5 \\
\hline 3. Anlamayı Paylaşma Aşaması & 0 \\
\hline Etkinlikten Alınan Toplam Puan & $\mathbf{1 0}$ \\
\hline
\end{tabular}

Tablo 4'e göre Osmanlı Devletinde fethedilen yerler ile ilgili etkinliğin SDÖ'ye kısmen uygun olduğu söylenebilir. Zira bu etkinlik toplamda 24 puandan ancak 10 puan almıştır. Bu etkinlikte araştırmaya odaklama ve sorgulamayı başlatma aşamalarına en fazla yer verilirken anlamayı paylaşma aşamasına ise hiç yer verilmemiştir. Şekil 4'te Osmanlı Devletinde fethedilen yerlere yönelik etkinlik verilmiştir. 


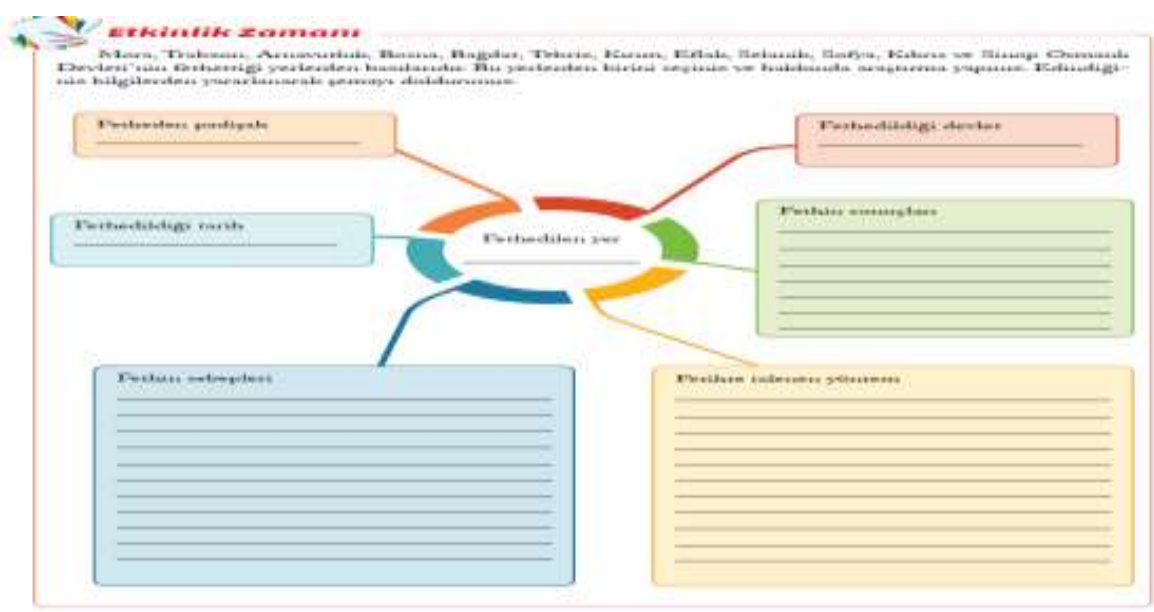

Şekil 4. Osmanlı Devletinde Fethedilen Yerlere Yönelik Etkinlik

Şekil 4'te yer alan Osmanlı Devletinde fethedilen yerlere yönelik etkinlik incelendiğinde öğrencilerden Osmanlı Devletinde döneminde fethedilen bazı yerlerin araştırılması istenmiştir. Bu etkinlikte öğrencilerden araştırdıkları yerlerle ilgili bazı bilgilerin etkinlik kâğıdı üzerinde doldurmaları istenmiştir.

\section{ülkemizde Nüfus Ünitesinde Yer Alan Kudüs Şehri Etkinliğine Yönelik Bul- gular}

Bu bölümde Ülkemizde Nüfus Ünitesinde yer alan Kudüs şehrine yönelik etkinliğin ASDEÖ'ye uygunluğu incelenmiştir. Bu etkinliğin ASDEÖ'ye uygunluğu aşamalar halinde Tablo 5'te verilmiştir.

Tablo 5. Kudüs Şehri Etkinliğinin ASDEÖ'ye Uygunluğu

\begin{tabular}{ll}
\hline ASDEÖ'nün Aşamaları & Alınan Puan \\
\hline 1. Sorgulamayı Başlatma Aşaması & 5 \\
\hline 2. Araştırmaya Odaklama Aşaması & 6 \\
\hline 3. Anlamayı Paylaşma Aşaması & 0 \\
\hline Etkinlikten Alınan Toplam Puan & $\mathbf{1 1}$ \\
\hline
\end{tabular}

Tablo 5'e göre Kudüs şehri ile ilgili etkinliğin SDÖ'ye kısmen uygun olduğu söylenebilir. Zira bu etkinlik kapsamında ASDEÖ'den toplamda 24 puandan ancak 11 puan alınmıştır. Bu etkinlikte araştırmaya odakla- 
ma aşamasına en fazla yer verilirken anlamayı paylaşma aşamasına ise hiç yer verilmemiştir. Şekil 5'te Kudüs şehrine yönelik etkinlik verilmiştir.

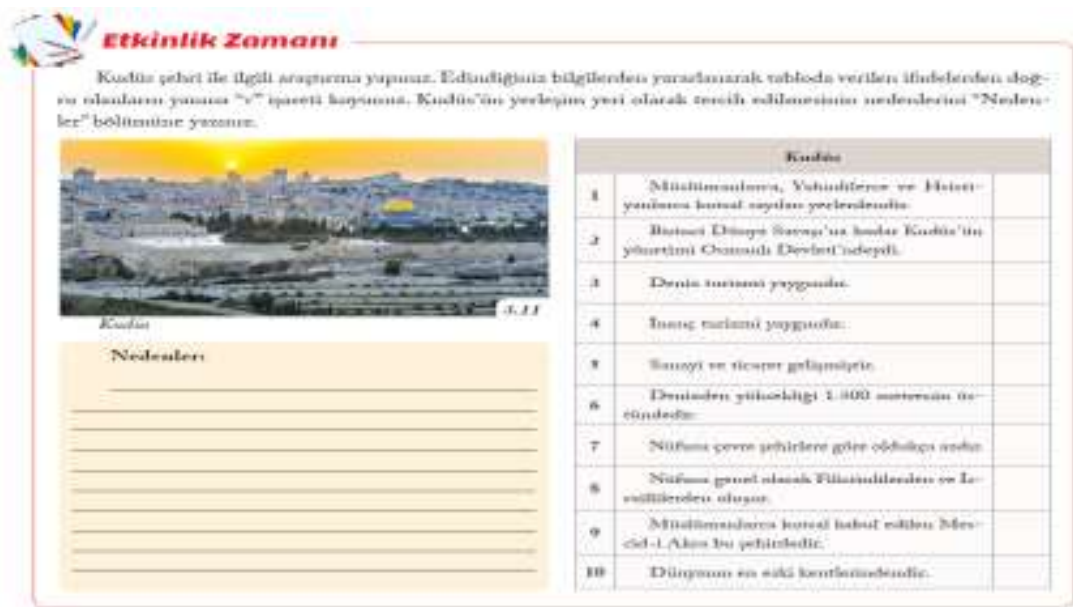

Şekil 5. Kudüs Şehrine Yönelik Etkinlik

Şekil 5'te yer alan Kudüs şehrine yönelik etkinlik incelendiğinde öğrencilerden Kudüs şehri ile ilgili bir araştırma yapmaları istenmiştir. Bu etkinlikte öğrencilerden Kudüs şehrinin bir yerleşim yeri olarak tercih edilmesinin nedenlerini yazmaları ve Kudüs şehri ile ilgili bazı bilgilerin etkinlik kâğıdı üzerinde doldurmaları istenmiştir.

\section{Zaman İçinde Bilim Ünitesindeki Türk İslam Medeniyetinde Yetişen Bilgin- ler Etkinliğine Yönelik Bulgular}

Bu bölümde Zaman İçinde Bilim Ünitesinde yer alan Türk İslam medeniyetinde yetişen bilginlere yönelik etkinliğin ASDEÖ'ye uygunluğu incelenmiştir. Bu etkinliğin ASDEÖ’ye uygunluğu aşamalar halinde Tablo 6'da verilmiştir.

Tablo 6. Türk İslam Medeniyetinde Yetişen Bilginler Etkinliğinin ASDEÖ'ye Uygunluğu

\begin{tabular}{ll}
\hline ASDEÖ'nün Aşamaları & Alınan Puan \\
\hline 1. Sorgulamayı Başlatma Aşaması & 5 \\
\hline 2. Araştırmaya Odaklama Aşaması & 3 \\
\hline 3. Anlamayı Paylaşma Aşaması & 0 \\
\hline Etkinlikten Alınan Toplam Puan & $\mathbf{8}$ \\
\hline
\end{tabular}


Tablo 6'ya göre Türk İslam Medeniyetinde Yetişen Bilginler ile ilgili etkinliğin SDÖ'ye kısmen uygun olduğu söylenebilir. Zira bu etkinlik kapsamında ASDEÖ'den toplamda 24 puandan ancak 8 puan alınmıştır. $\mathrm{Bu}$ etkinlikte sorgulamayı başlatma aşamasına en fazla yer verilirken anlamayı paylaşma aşamasına ise hiç yer verilmemiştir. Şekil $6^{\prime}$ da Türk İslam Medeniyetinde Yetişen Bilginlere yönelik etkinlik verilmiştir.

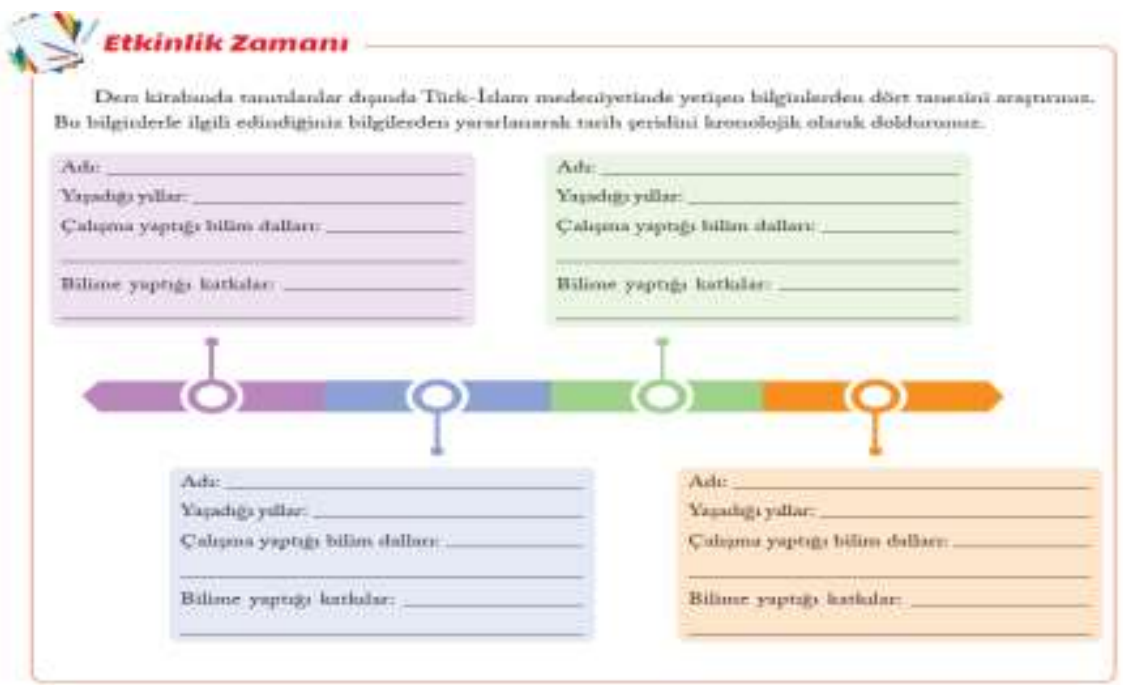

Şekil 6. Türk İslam Medeniyetinde Yetişen Bilginlere Yönelik Etkinlik

Şekil 6'da yer alan Türk İslam Medeniyetinde yetişen bilginlere yönelik etkinlik incelendiğinde öğrencilerden Türk İslam Medeniyetinde yetişen bilginlerden dört tanesi ile ilgili olarak; bu bilginlerin yaşadığı dönem, çalışma yaptıkları bilim dalları ve bilime yaptıkları katkıların araştırılması istenmiştir. Bu etkinlikte daha sonra öğrencilerden araştırdıkları bilginlerle ilgili araştırma sonuçlarının etkinlik kâğıdı üzerinde kronolojik olarak doldurmaları istenmiştir.

\section{Ekonomi ve Sosyal Hayat Ünitesinde Yer Alan Tarmı Destekleyen Kurum ve Kuruluşlar Etkinliğine Yönelik Bulgular}

Bu bölümde Ekonomi ve Sosyal Hayat Ünitesinde yer alan Tarımı Destekleyen Kurum ve Kuruluşlar etkinliğinin ASDEÖ'ye uygunluğu ince- 
lenmiştir. Bu etkinliğin ASDEÖ'ye uygunluğu aşamalar halinde Tablo 7'de verilmiştir.

Tablo 7. Tarımı Destekleyen Kurum ve Kuruluşlar Etkinliğinin ASDEÖ'ye Uygunluğu

\begin{tabular}{ll}
\hline ASDEÖ'nün Aşamaları & Alınan Puan \\
\hline 1. Sorgulamayı Başlatma Aşaması & 5 \\
\hline 2. Araştırmaya Odaklama Aşaması & 6 \\
\hline 3. Anlamayı Paylaşma Aşaması & 0 \\
\hline Etkinlikten Alınan Toplam Puan & $\mathbf{1 1}$ \\
\hline
\end{tabular}

Tablo 7'ye göre Tarımı Destekleyen Kurum ve Kuruluşlar ile ilgili etkinliğin SDÖ'ye kısmen uygun olduğu söylenebilir. Zira bu etkinlik kapsamında ASDEÖ’den toplamda 24 puandan ancak 11 puan alınmıştır. Bu etkinlikte araştırmaya odaklama aşamasına en fazla yer verilirken anlamayı paylaşma aşamasına ise hiç yer verilmemiştir. Şekil 7'de Tarımı Destekleyen Kurum ve Kuruluşlara yönelik etkinlik verilmiştir.

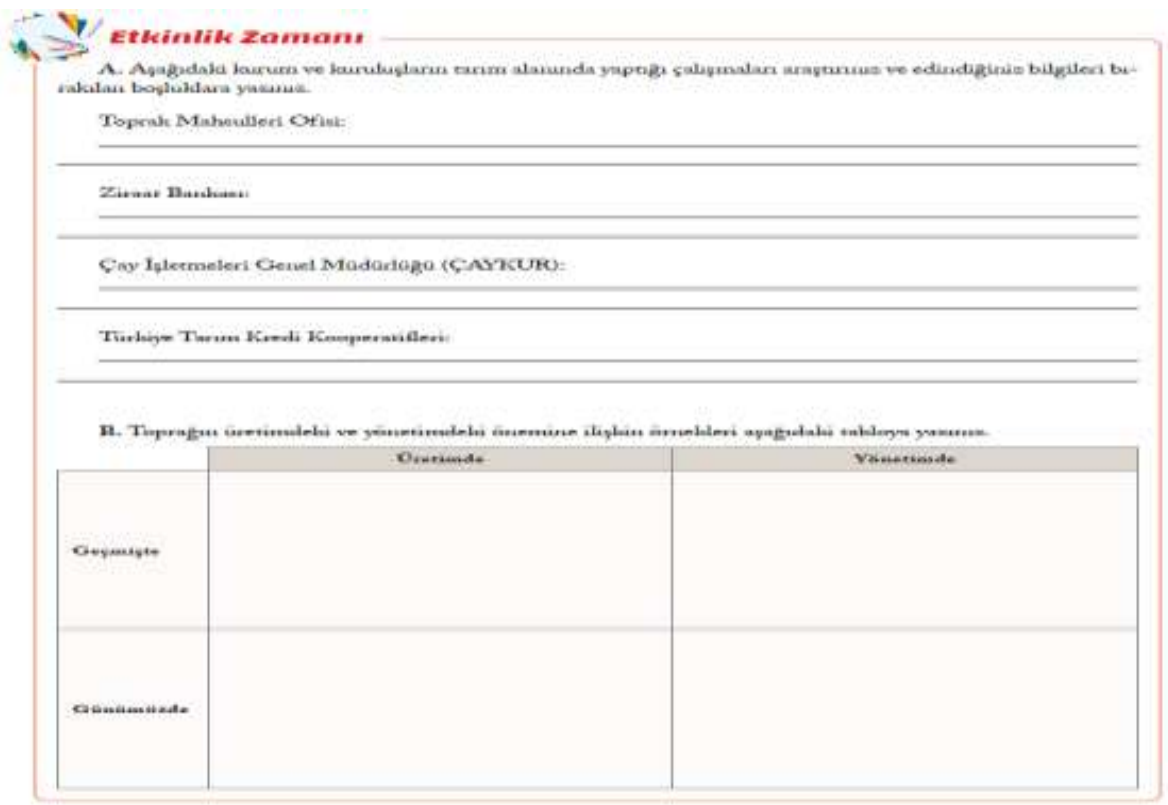

Şekil 7. Tarımı Destekleyen Kurum ve Kuruluşlara Yönelik Etkinlik

Şekil 7'de yer alan Tarımı Destekleyen Kurum ve Kuruluşlara yönelik etkinlik incelendiğinde öğrencilerden tarımı destekleyen kurum ve kuru- 
luşlar ile ilgili bir araştırma yapmaları istenmiştir. Daha sonra bu etkinlikte öğrencilerden toprağın üretim ve yönetimdeki önemine ilişkin geçmiş ve günümüzdeki durumu ile ilgili bilgilerin etkinlik kâğıdına doldurmaları istenmiştir.

\section{Ekonomi ve Sosyal Hayat Ünitesinde Yer Alan Türk Kızılayı Etkinliğine Yönelik Bulgular}

Bu bölümde Ekonomi ve Sosyal Hayat Ünitesinde yer alan Türk Kızılayı etkinliğinin ASDEÖ’ye uygunluğu incelenmiştir. Bu etkinliğin ASDEÖ'ye uygunluğu aşamalar halinde Tablo 8'de verilmiştir.

Tablo 8. Türk Kızılay'ı Etkinliğinin ASDEÖ'ye Uygunluğu

\begin{tabular}{ll}
\hline ASDEÖ'nün Aşamaları & Alınan Puan \\
\hline 1. Sorgulamayı Başlatma Aşaması & 5 \\
\hline 2. Araştırmaya Odaklama Aşaması & 6 \\
\hline 3. Anlamayı Paylaşma Aşaması & 0 \\
\hline Etkinlikten Alınan Toplam Puan & $\mathbf{1 1}$ \\
\hline
\end{tabular}

Tablo 8'e göre Türk Kızılayı ile ilgili etkinliğin SDÖ’ye kısmen uygun olduğu söylenebilir. Zira bu etkinlik kapsamında ASDEÖ'den toplamda 24 puandan ancak 11 puan alınmıştır. Bu etkinlikte araştırmaya odaklama aşamasına en fazla yer verilirken anlamayı paylaşma aşamasına ise hiç yer verilmemiştir. Şekil 8'de Türk Kızılayına yönelik etkinlik verilmiştir.

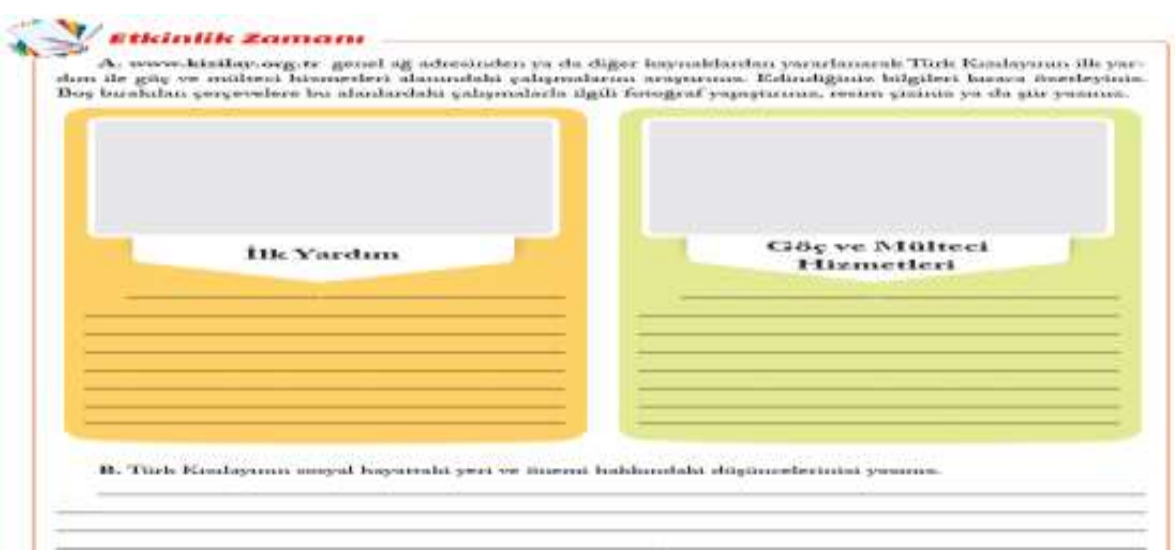

Şekil 8. Türk Kızılayına Yönelik Etkinlik 
Şekil 8'de yer alan Türk Kızılayına yönelik etkinlik incelendiğinde öğrencilerden Türk Kızılay'ının ilk yardım, göç ve mültecilere yönelik hizmetleri ile ilgili bir araştırma yaparak bu araştırmayla ilgili resim, şiir yapmaları ya da fotoğraf bulmaları istenmiş̧tir. Daha sonra öğrencilerden Türk Kızılayının sosyal hayattaki yeri ve önemi ile ilgili düşüncelerini etkinlik kâğıdına doldurmaları istenmiştir.

Yaşayan Demokrasi Ünitesinde Yer Alan Türk Devletlerinin Yönetim Biçimleri Etkinliğine Yönelik Bulgular

Bu bölümde Yaşayan Demokrasi Ünitesinde yer alan Türk Devletlerinin Yönetim Biçimleri etkinliğinin ASDEÖ'ye uygunluğu incelenmiştir. Bu etkinliğin ASDEÖ’ye uygunluğu aşamalar halinde Tablo 9'da verilmiştir.

Tablo 9. Türk Devletlerinin Yönetim Biçimleri Etkinliğinin ASDEÖ'ye Uygunluğu

\begin{tabular}{ll}
\hline ASDEÖ'nün Aşamaları & Alınan Puan \\
\hline 1. Sorgulamayı Başlatma Aşaması & 4 \\
\hline 2. Araştırmaya Odaklama Aşaması & 6 \\
\hline 3. Anlamayı Paylaşma Aşaması & 0 \\
\hline Etkinlikten Alınan Toplam Puan & $\mathbf{1 0}$ \\
\hline
\end{tabular}

Tablo 9'a göre Türk Devletlerinin Yönetim Biçimleri ile ilgili etkinliğin SDÖ'ye kısmen uygun olduğu söylenebilir. Zira bu etkinlik kapsamında ASDEÖ'den toplamda 24 puandan ancak 10 puan alınmıştır. Bu etkinlikte araştırmaya odaklama aşamasına en fazla yer verilirken anlamayı paylaşma aşamasına ise hiç yer verilmemiştir. Şekil 9'da Türk devletlerinin yönetim biçimlerine yönelik etkinlik verilmiştir. 


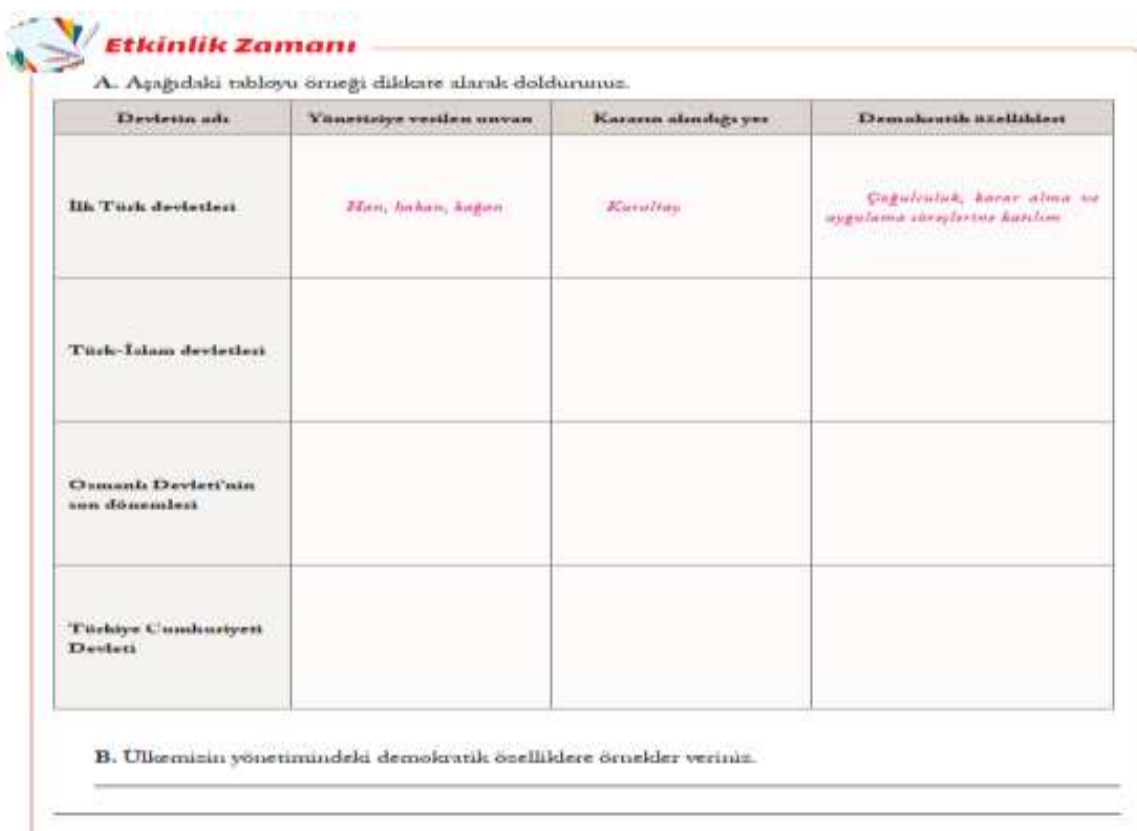

Şekil 9. Türk Devletlerinin Yönetim Biçimlerine Yönelik Etkinlik

Şekil 9'da yer alan Türk Devletlerinin Yönetim Biçimlerine yönelik etkinlik incelendiğinde öğrencilerden geçmişten günümüze Türk devletlerinde yöneticilere verilen unvanlar, kararların alındığı yer ve demokratik özellikleri ile ilgili bir araştırma yapmaları istenmiştir. Daha sonra bu etkinlikte öğrencilerden ülkemizin yönetimindeki demokratik özelliklerine verecekleri örnekleri etkinlik kâğıdına doldurmaları istenmiştir.

\section{Ülkeler Arası Köprüler Ünitesindeki Etkinliğe Yönelik Bulgular}

Bu bölümde Ülkeler Arası Köprüler Ünitesinde yer alan G20 ülkeleri etkinliğinin ASDEÖ'ye uygunluğu incelenmiştir. Bu etkinliğin ASDEÖ'ye uygunluğu aşamalar halinde Tablo 10'da verilmiştir.

\section{Tablo 10. G20 Ülkeleri Etkinliğinin ASDEÖ'ye Uygunluğu}

\begin{tabular}{ll}
\hline ASDEÖ'nün Aşamaları & Alınan Puan \\
\hline 1. Sorgulamayı Başlatma Aşaması & 6 \\
\hline 2. Araştırmaya Odaklama Aşaması & 8 \\
\hline 3. Anlamayı Paylaşma Aşaması & 0 \\
\hline Etkinlikten Alınan Toplam Puan & $\mathbf{1 4}$ \\
\hline
\end{tabular}


Tablo 10'a göre G20 ülkeleri ile ilgili etkinliğin SDÖ'ye kısmen uygun olduğu söylenebilir. Zira bu etkinlik kapsamında ASDEÖ'den toplamda 24 puandan ancak 14 puan alınmıştır. Bu etkinlikte araştırmaya odaklama aşamasına en fazla yer verilirken anlamayı paylaşma aşamasına ise hiç yer verilmemiştir. Şekil 10'da G20 Ülkelerine yönelik etkinlik verilmiştir.

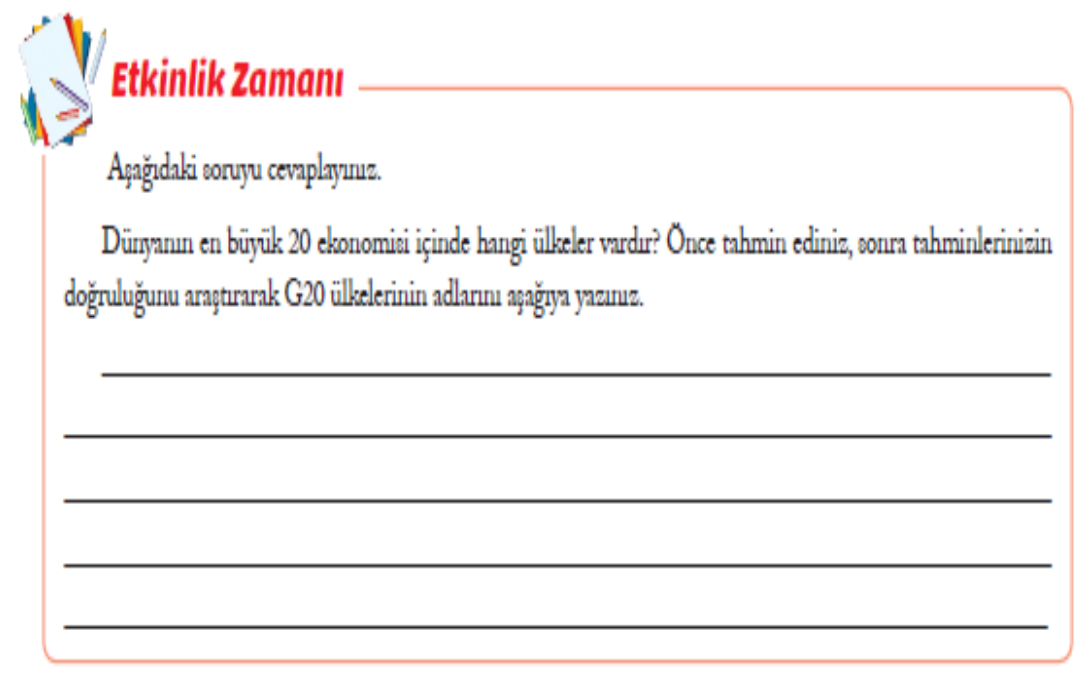

Şekil 10. G20 Ülkelerine Yönelik Etkinlik

Şekil 10'da yer alan G20 ülkelerine yönelik etkinlik incelendiğinde etkinliğin başında öğrencilerden dünyanın en büyük 20 ekonomisi içinde hangi ülkelerin olduğu sorulmuştur. Daha sonra öğrencilerden G20 ülkelerinin isimlerini tahmin etmeleri istenmiş ve bu tahminlerin doğruluğu ile ilgili bir araştırma yaparak G20 ülkeleri ile ilgili araştırma sonuçlarını etkinlik kâğıdına doldurmaları istenmiştir.

\section{Tüm Etkinliklerin ASDEÖ'ye Uygunluğuna Yönelik Aldı̆̆ı Puanlar}

Bu bölümde, bu çalışma kapsamında incelenen tüm etkinliklerin ASDEÖ'ye uygunluğuna yönelik aldığı toplam puanlara yer verilmiştir. Tüm etkinliklerin ASDEÖ'ye uygunluğuna yönelik aldığı puanlar Tablo 11 'de verilmiştir. 
Tablo 11. Tüm Etkinliklerin ASDEÖ'ye Uygunluğuna Yönelik Aldığı Puanlar

\begin{tabular}{lllll}
\hline İncelenen Etkinlikler & $\begin{array}{l}\text { Sorgulamayı } \\
\text { Başlatma }\end{array}$ & $\begin{array}{l}\text { Araştırmaya } \\
\text { Odaklama }\end{array}$ & $\begin{array}{l}\text { Anlamayı } \\
\text { Paylaşma }\end{array}$ & $\begin{array}{l}\text { Alınan } \\
\text { Puanlar }\end{array}$ \\
\hline 1. Genel Ağ & 3 & 6 & 0 & 9 \\
2. Osmanlı Devleti Döneminde Sanat Dalları & 4 & 6 & 0 & 10 \\
3. Rönesans ve Aydınlanma Çağı & 4 & 5 & 0 & 9 \\
4. Osmanlı Devletinde Fethedilen Yerler & 5 & 5 & 0 & 10 \\
5. Kudüs Şehri & 5 & 6 & 0 & 11 \\
6. Türk İlam Medeniyetinde Yetişen Bilginler & 5 & 3 & 0 & 8 \\
7. Tarımı Destekleyen Kurum ve Kuruluşlar & 5 & 6 & 0 & 11 \\
8. Türk Kızllayı & 5 & 6 & 0 & 11 \\
9. Türk Devletlerinin Yönetim Biçimleri & 4 & 6 & 0 & 10 \\
10. G20 Ülkeleri & 6 & 8 & 0 & 14 \\
\hline Toplam Puanlar & $\mathbf{4 6}$ & $\mathbf{5 7}$ & $\mathbf{0}$ & $\mathbf{1 0 3}$ \\
\hline
\end{tabular}

Tablo 11'e göre etkinliklerin ASDEÖ'ye uygunluğu incelendiğinde tüm etkinliklerde en çok araştırmaya odaklama aşamasına (57 puan) yer verilirken ikinci sırada sorgulamayı başlatma aşamasına (46 puan) yer verilmiştir ancak bu çalışma kapsamında incelenen hiçbir etkinlikte anlamayı paylaşma aşamasına yer verilmemiştir. Tüm etkinliklerin ortalaması ise 10,3 tür ve bu sonuç yaklaşık olarak \%43'e denk gelmektedir. Bu sonuç bu çalışma kapsamında incelenen tüm etkinliklerin SDÖ’ye uygunluk açısından kısmen uygun olduğunu göstermiştir.

Etkinliklerdeki Maddelerin ASDEÖ'ye Uygunluğuna Yönelik Aldı̆̆ı Toplam Puanlar

ASDEÖ toplam 12 maddeden oluşmaktadır. Etkinliklerde yer alan maddelerin ASDEÖ'ye uygunluğuna yönelik aldığı toplam puanlar Tablo 12 'de verilmiştir. 
Tablo 12. Etkinliklerde Yer Alan Maddelerin ASDEÖ'ye Uygunluğuna Yönelik Aldı̆̆ı Toplam Puanlar

\begin{tabular}{lc}
\hline Etkinliklerde Yer Alan Maddelerin İçeriği & Puan \\
\hline 1. Etkinlikte öğrencilerin ön bilgilerinin ortaya çıkarılması & 12 \\
\hline 2. Etkinlikte öğrencilere araştırabilecekleri türde sorular sorulması & 17 \\
\hline 3. Etkinlikte öğrencilerin merak ettikleriyle öğretilmesi planlanan içerik arasında ilişkinin kurulması & 18 \\
\hline 4. Etkinliğin öğrencileri materyallerle etkileşime sevk etmesi & 20 \\
\hline 5. Etkinliğin öğrencileri gözlem yapmaya sevk etmesi & 0 \\
\hline \begin{tabular}{l} 
6. Etkinliğin öğrencileri olası açılamalar yapmaya sevk etmesi \\
\hline 7. Etkinliğin öğrencileri tahmin yapmaya ve bu tahminleri test etmeye sevk etmesi
\end{tabular} \\
\hline $\begin{array}{l}\text { 8. Etkinliğin öğrencileri sorulara tekrar döndürmeye ve gözlemler sonucunda açıklamalar getirme- } \\
\text { ye sevk etmesi }\end{array}$ & 0 \\
\hline $\begin{array}{l}\text { 9. Etkinliğin öğrencilerin düşüncelerini, verilerini, bulgularını yazma-çizme gibi yöntemlerle kay- } \\
\text { detmeye ve sunmaya sevk etmesi }\end{array}$ & 10 \\
\hline $\begin{array}{l}\text { 10. Etkinlikte öğrencilere yaptıklarını, düşüncelerini toparlamak ve başkalarıyla nasıl paylaşacağını } \\
\text { planlamak için süre verilmesi }\end{array}$ & 0 \\
\hline $\begin{array}{l}\text { 11. Etkinlikte gruplara birbirlerinin fikirleriyle ilgili yorum yapma ve ek fikirler ortaya koyma şansı } \\
\text { verilmesi }\end{array}$ & 0 \\
\hline $\begin{array}{l}\text { 12. Etkinlikte öğretmene grupların verilerinden ve fikirlerinden yararlanarak konuyu özetleme fırsatı } \\
\text { verilmesi }\end{array}$ & 0 \\
\hline Maddelerin Aldığı Toplam Puan & $\mathbf{1 0 3}$ \\
\hline
\end{tabular}

Tablo 12'ye göre; etkinlikler kapsamında incelenen üç madde SDÖ'ye kısmen uygun, dört madde uygun ancak beş madde ise hiç uygun değildir. Etkinliklerde yer alan tüm maddeler öğrencileri materyallerle etkileşime sevk etmektedir ancak hiçbir etkinlikte, öğrencilerin gözlem yapmasına, araştırmalarını paylaşmasına, grup çalışmasına ve öğretmenin konuyu özetlemesine yer verilmemiştir. Tüm maddelerden alınan puanların ortalaması ise 20 puan üzerinden yaklaşık olarak 8,58' dir. Bu ortalama da yaklaşık olarak \%43'e denk gelmektedir. Bu sonuç etkinlikler kapsamında incelenen tüm maddelerin ortalama puanlarının SDÖ'ye uygunluk açısından kısmen uygun olduğunu göstermiştir.

\section{Tartışma, Sonuç ve Öneriler}

Bostan Sarığlan, Can ve Gedik (2016) yaptıkları çalışma kapsamında inceledikleri 6. sınıf fen bilimleri ders kitabındaki etkinliklerin hiçbirinin ASDEÖ ile analizi sonucu tam puan alamadığını tespit etmişlerdir. Yapılan bu çalışma sonucunda da benzer bir sonuca ulaşılmıştır. Hatta bu çalışmada incelenen etkinliklerin büyük çoğunluğunun SDÖ doğrultusunda çok daha düşük puanlar aldığı tespit edilmiştir. Bu duruma yol açan en önemli faktörün 
SDÖ'nün ülkemizde sosyal bilgiler eğitiminde pek fazla uygulanmamasından kaynaklanmış olabilir.

Bostan Sarıoğlan, Can ve Gedik (2016) yaptıkları çalışma kapsamında 6. sınıf fen bilimleri ders kitabındaki etkinlikleri tek tek incelediklerinde, etkinliklerde 'araştırmaya odaklama' ölçütlerinin gerekleri, 'sorgulamaya başlatma' ve 'anlamayı paylaşma' ölçütleri gereklerine göre daha çok yer bulmuştur. Ancak yapılan bu çalışma sonucunda anlamayı paylaşma aşamasına hiç yer verilmemiştir. Bu anlamda 7. sınıf sosyal bilgiler ders kitabında yer alan etkinliklerde öğrencilere yaptıklarını, düşüncelerini toparlamak ve başkalarıyla paylaşmalarına yer verilmemesinin oldukça olumsuz bir yaklaşım olduğu söylenebilir. Zira öğrencilerin yaptıkları araştırmalarını öğretmenleriyle ve arkadaşlarıyla paylaşmamaları motivasyonları, derse olan tutumları ve öğrenmeleri açısından oldukça olumsuz bir sonuç olarak değerlendirilebilir. Bu sonucun sosyal bilgiler ders saatinin yetersiz olmasından kaynaklanmış olabilir. Zira öğretim programlarının belirlediği hedefler doğrultusunda hazırlanan ders kitaplarında yer alan içerikler, etkinlikler ve ölçme-değerlendirmeler belirli bir zamana göre düzenlenmektedir.

Bostan Sarığlan, Can ve Gedik (2016) yaptıkları çalışma kapsamında inceledikleri etkinliklerde araştırmaya odaklama aşaması oldukça yüksek oranda yer almaktadır. Bu çalışma sonucunda da benzer bir sonuca ulaşılmıştır. Zira bu çalışma kapsamında incelenen etkinliklerin yaklaşık olarak \%60'ı araştırmaya odaklama aşamasıyla ilgilidir. Bu çalışmada araştırmaya odaklama aşamasında; öğrenciler materyallerle etkileşime, olası açıklamalar yapmaya, tahmin yürütmeye düşüncelerini, verilerini ve bulgularını yazma gibi yöntemlerle kaydetmeye sevk edildiği görülmektedir. Ancak bu çalışma sonuçlarına göre öğrencilere; gözlem yapmaya, gözlem sonucunda açıklama yapmaya, tahminleri test etmeye, öğrencileri sorulara tekrar döndürmeye ise hemen hemen hiç verilmediği tespit edilmiştir.

Tatar ve Kuru'ya (2006) göre öğrenciler, araştırdıkları ve keşfettikleri bilgileri analiz etmeli, yorumlamalı ve sunmalıdır ancak yapılan bu çalışma sonuçlarına göre incelenen hiçbir etkinlikte öğrenciler araştırdıkları bilgileri veya keşfettiklerini sunma ve paylaşma fırsatı verilmemiştir. Bu durum eğitim-öğretim açısından olumsuz bir yaklaşım olarak değerlendirilebilir. Bu yaklaşımın sosyal bilgiler ders saatinin haftada üç saat 
olmasından yani yetersiz olmasından kaynaklanmış olabilir. Her ne kadar sosyal bilgiler ders saatinin yetersiz olduğu düşünülse de en azından bazı etkinliklerde öğrencilere araştırdıkları çalışmaları paylaşmaları ve sunma olanağ1 verilmesi gerekir.

Coffman'a (2017) göre; SDÖ Stratejisi ile öğrencilere işbirlikçi bir ortamdaki içeriği öğrenme ve keşfetme olanağı verilir. Bu çalışma sonuçlarına göre öğrencilere yaptıkları hiçbir araştırmada grup çalışmasına ve işbirliği yapılmasına olanak verilmemiştir. Oysa öğrenciler akranlarıyla oluşturdukları gruplarda işbirliği yaparak daha iyi öğrenebilirler ve öğrenmeleri yapacakları araştırmalar sayesinde daha zevkli ve eğlenceli olabilir. Nitekim Read ve Rees'e (2006) göre; erken çocukluk eğitimi imkanları, çocukların iş birliği içinde çalışabilmesi ve etkili bir grubun üyesi olması memnuniyet ve destek kaynağıdır.

$\mathrm{Bu}$ çalışma sonuçlarına göre öğrencilerin yaptığı hiçbir araştırmada öğretmenlere öğrencilerin yaptığ fikirlerinden yararlanarak ilgili konuyu özetleme fırsatı verilmemiştir. Bu doğrultuda Jones'e (2009) göre; SDÖ sürecinin başarılı bir şekilde gerçekleştirilmesi için öğretmenlerin bunun farkında olması ve SDÖ ilerledikçe bu öğretim ortamının şeklini ve yapısını etkin bir biçimde düzenlemesi gerekir. Benzer şekilde Harlen'e (2004; aktaran Duban, 2016) göre; SDÖ sürecinde öğretmenler derse başlamadan önce öğrencilerin ön bilgilerini değerlendirmeli ve öğretilecek yeni kavramlar için bu ön bilgileri dikkate almalıdır.

$\mathrm{Bu}$ çalışma açısından bir başka olumsuz bir sonuç ise etkinliklerde öğrenciler yaptıkları hiçbir araştırmada gözlem yapmaya sevk edilmemiş ve etkinlikler öğrencileri sorulara tekrar döndürmeye ve gözlemler sonucunda açıklamalar yapmaya sevk etmemiştir. Gözlem yapmak bilimin ve araştırmanın doğasında olan önemli bir faaliyettir. Öğrencilerin yaptıkları gözlemleri not almaları, hazırlayacakları soruları sormaları ve yapacakları gözlemler sonucunda açılamalar ve yorumlar yapmaları SDÖ süreci açısından da oldukça önemli bir unsurdur. Nitekim Kselman'a (2003) ve Taşkoyan'a (2008) göre; SDÖ öğrencilerin öğrendikleri bilgileri yapılandırmak amacıyla bilim insanlarınkine benzer yöntem ve uygulamaları izlediği bir stratejidir.

Bu çalışmada ülkemizde 2019-2020 eğitim-öğretim yılında MEB tarafından okutulan EKOYAY'a ait 7. sinıf sosyal bilgiler ders kitabında yer 
alan etkinliklerin SDÖ'ye uygunluğunun değerlendirilmesi yapılmıştır. $\mathrm{Bu}$ çalışma kapsamında yedi öğrenme alanı altında yer alan toplam 101 etkinlik içinde 10 etkinlik SDÖ'ye uygunluk açısından incelenmiştir. Bu çalışma sonuçlarına göre; araştırma kapsamında incelenen etkinliklerin tamamı SDÖ'ye kısmen uygundur. İncelenen tüm etkinliklerde en çok araştırmaya odaklama aşamasına yer verilirken anlamayı paylaşma aşamasına ise hiç yer verilmemiştir. Bu çalışma kapsamında SDÖ́ye en uygun olan etkinlik G20 Ülkeleri etkinliği iken SDÖ'ye en az uygun olan etkinlik ise Türk İslam Medeniyetinde Yetişen Bilginler etkinliğidir.

$\mathrm{Bu}$ çalışma sonuçlarına göre; etkinliklerin tamamı öğrencileri materyallerle etkileşime sevk etmektedir. Etkinliklerin önemli bir bölümünde öğrencilerin merak ettikleriyle öğretilmesi planlanan içerik arasında ilişki kurulmuştur. Öğrenciler etkinliklerle ilgili olası açıklamalar yapmaya sevk edilmiş ve öğrencilere araştırabilecekleri türde sorular sorulmuştur. Etkinliklerde kısmen öğrencilerin ön bilgileri ortaya çıkarılmış, öğrenciler düşüncelerini, verilerini ve bulgularını yazma-çizme gibi yöntemlerle kaydetmeye ve sunmaya sevk edilmiş ve öğrenciler tahmin yürütmeye ve bu tahminleri test etmeye sevk edilmiştir. Ancak etkinliklerin hiçbirinde öğrenciler gözlem yapmaya sevk edilmemiş, öğrencileri sorulara tekrar döndürmeye ve öğrenciler gözlemler sonucunda açılamalar yapmaya sevk edilmemiştir. Öğrencilere yaptıklarını, düşüncelerini toparlamak ve başkalarıyla nasıl paylaşacaklarına olanak verilmemiş ve öğrenci gruplarına birbirlerinin fikirleri ile ilgili yorum yapma ve ek fikirler ortaya sunma şansı verilmemiştir. Son olarak öğretmenlere grupların verilerinden ve fikirlerinden yararlanarak ilgili konuyu özetleme imkanı verilmemiştir.

Bu çalışma kapsamında elde edilen bulgular doğrultusunda aşağıdaki önerilere yer verilmiştir:

1. Öğrencilere yaptıkları araştırmaları, düşüncelerini açıklamak ve başkalarıyla nasıl paylaşacağını planlamak için yeterli bir süre verilmelidir.

2. Öğrencilere yaptıkları etkinlerde birbirlerinin fikirleriyle ilgili yorum yapmaları ve ek düşünceler ortaya koymaları için fırsat verilmelidir.

3. Öğretmenlere öğrencilerin verilerinden ve fikirlerinden yararlanarak ilgili konuyu özetleme fırsatı verilmelidir.

4. Öğrencilere yaptıkları araştırmalarda gözlem yapmaya, yaptıkları tahminleri test etmeye ve açıklamalar yapmalarına olanak verilmelidir. 


\title{
EXTENDED ABSTRACT
}

\section{The Evaluation of the Suitability of the Activities in the 7th Grade Social Studies Textbook for Inquiry-Based Teaching}

\author{
Turan Kaçar - Cengiz Taşkıran \\ Ministry of National Education, Muş AlparslanUniversity
}

It can be said that the textbooks, which are frequently used both inside and outside the school, are an important resource and teaching tool for students. For this purpose, in the textbooks; written materials, pictures, photographs, graphics, date strips, cartoons, evaluations, activities and maps. According to Gönen, Katranc1, Uygun and Uçuş (2011), books prepared to make reading enjoyable and entertaining play a major role in the development of primary school children as individuals who enjoy reading. In this context, it is very important to apply new strategies, methods and techniques in the contents, teaching process, activities and researches in the textbooks for students to enjoy reading and to learn with fun. In this respect, it can be stated that one of the new strategies that can be applied in the teaching process is the Inquiry Based Learning (IBL) strategy, which is not often applied in social studies education. Güneş (2014) takes IBL as one of the strategies within the constructivist learning approach, Hırça (2015), on the other hand, considers it to be one of the most effective ways in which students take an active role in the classroom, are aware of the problems around them, produce different solutions to these problems, and enable them to continue the learning process more effectively.

In this study, it was tried to examine to what extent the activities in the 7th grade social studies textbook taught by the Ministry of National Education in Turkey in the 2019-2020 academic year are appropriate for the Research-Inquiry-Based Activity Scale developed by Bostan Sarıoğlan, Can and Gedik (2016). According to Yıldırım and Şimşek (2013), document analysis is a technique that includes the analysis of written materials that contain information about the phenomenon or 
facts to be investigated. For this purpose, first of all, permission was obtained from the researchers (Bostan Sarıoglan, Can and Gedik, 2016) who developed Research-Inquiry-Based Activity Scale. The Research-InquiryBased Activity Scale, developed by these researchers, consists of three parts (Initiating inquiry, Focusing on research, and Sharing understanding) and a total of 12 items. In this direction, all activities (101 activities) in the 7 th grade social studies textbook were examined. In addition, a total of 10 activities, including at least one activity in each unit, were examined according to the ratio of activities in the units. Later, the activities that were examined were coded and filled out by two researchers in line with the Research-Inquiry-Based Activity Scale. In this direction, 10 activities in the 7th grade social studies textbook that the Ministry of National Education teaches in Turkey in the 2019-2020 academic year were evaluated according to the Research-Inquiry-Based Activity Scale developed by Bostan Sarığlan, Can and Gedik (2016). This study was conducted with the document analysis technique, which is one of the qualitative research methods. When the literature is examined, ResearchInquiry-Based Activity Scale, which was developed by Bostan Sarıoglan, Can and Gedik (2016), which was thought to be suitable for this study, was determined as a data collection tool. In this study, the descriptive analysis technique was used to analyze the data.

According to the results of this study; All of the activities encourage students to interact with the materials. In most of the activities, a relationship has been established between the curiosity of the students and the content they are planned to teach. The students were encouraged to make possible explanations about the activities and the students were asked questions that they could investigate. In the activities, students' prior information was partially revealed, students were encouraged to record and present their thoughts, data and findings using methods such as writing and drawing, and the students were encouraged to make predictions and test these predictions. However, in none of the activities, students were not prompted to make observations, they were not encouraged to return to questions and to make explanations as a result of observations. Students were not allowed to gather what they did, their thoughts and how to share them with others, and the student groups were not given the opportunity to comment on each other's ideas and to 
present additional ideas. Finally, the teachers were not given the opportunity to summarize the relevant topic using the data and ideas of the groups.

In line with the findings obtained within the scope of this study, the following recommendations are made:

1. Students should be given sufficient time to explain their research, thoughts and plan how they will share with others.

2. Students should be given the opportunity to comment on each other's ideas and put forward additional thoughts in their activities.

3. Teachers should be given the opportunity to summarize the relevant topic by making use of students' data and ideas.

4. Students should be allowed to observe, test their predictions and make explanations in their research.

\section{Kaynakça / References}

Bailey, L. A. (2018). The impact of inquiry-based learning on academic achievement in eighthgrade social studies. (Published doctoral dissertation). University of South Carolina, South Carolina, USA.

Bostan Sarıoğlan, A., Can, Y. ve Gedik, İ. (2016). 6. sunff fen bilimleri ders kitabındaki etkinliklerin araştırma-sorgulamaya dayalı öğrenme yaklaşımına uygunluğunun değerlendirilmesi. Abant İzzet Baysal Üniversitesi Eğitim Fakültesi Dergisi, 16(3), 1004-1025.

Coffman, T. (2017). Inquiry-based learning ( $3^{\text {th }}$ edition). Maryland: Rowman\&Littlefield.

Çalışkan, H. (2008). Ilköğretim 7. sinf sosyal bilgiler dersinde araștırmaya dayal öğrenme yaklaşımmin derse yönelik tutuma, akademik başarıya ve kahıllk düzeyine etkisi (Yayımlanmamış doktora tezi). Gazi Üniversitesi Eğitim Bilimleri Enstitüsü, Ankara.

Çalışkan, H. (2009). Sosyal bilgiler öğretiminde araştırmaya dayalı öğrenme yaklaşımının eleştirel düşünme becerisine etkisi. Kastamonu Eğitim Dergisi, 17(1), 5770.

Delice, A., Aydın E. ve Kardeş, D. (2009). Öğretmen adayı gözüyle matematik ders kitaplarında görsel ögelerin kullanım. İstanbul Ticaret Üniversitesi Fen Bilimleri Dergisi, 16, 75-92.

Demirel, Ö. ve Kıroğlu, K. (2019). Eğitim ve ders kitapları. (Ö. Demirel ve K. Kıroğlu Ed.). (3.baskı) Ders kitabı incelemesi içinde (s. 1-11). Ankara: Pegem Akademi. 
Duban, N. (2016). Sorgulanmaya dayalı öğrenme yaklaşımı. Ş. S.Anagün ve N. Duban (Ed.). Fen bilimleri öğretimi içinde (s. 221-240) içinde (2.baskı). Ankara: Anı Yayincilik.

Gök, F. (2003) Vatandaşlik ve insan haklan eğitimi ders kitapları, derskitaplarmda insan hakla$r$ : Tarama sonuçları içinde. İstanbul: Tarih Vakfı Yayınları.

Gönen, M., Katranc1, M., Uygun, M. ve Uçuş, Ş. (2011). Illköğretim birincikademe öğrencilerine yönelik çocuk kitaplarının, içerik,resimleme ve fiziksel özellikleri açısından incelenmesi. Eğitim ve Bilim Dergisi, 36(160), 250-265.

Gülersoy, A. E. (2013). İdeal ders kitabı arayışında sosyal bilgiler ders kitaplarının bazı özellikler açısından incelenmesi. International Journal of New Trends in Arts, Sports \& Science Education, 2(1), 8-26.

Güneş, F. (2014). Sorgulama tekniği. F. Güneş (Ed.). Öğretim ilke ve yöntemleri içinde (s. 375-377) (I.baskı). Ankara: Pegem Akademi Yayınclık.

Hırça, N. (2014). Sorgulamaya dayalı öğrenme. F. Güneş (Ed.). Öğrretim Ilke ve Yöntemleri içinde (s. 78-83) (1.baskı). Ankara: Pegem Akademi Yayıncilk.

İtter, İ. (2013). Sosyal bilgiler dersinde sorgulayıcı-araştırma tabanlı öğrenme modeli: Başarı ve öğrenmede kalıalığın etkisi. International Periodical For The Languages, Literature and History of Turkish or Turkic, 8(12), 591-605.

Jones, G. (2009). An inquiry-based learning approach to teaching information retrieval. Information Retrieval Journal, 12(2), 148-161. doi: 10.1007/s10791-0099088-x.

Kaçar, T. (2020). Sosyal bilgiler dersinde sorgulamaya dayah öğretimin öğrencilerin ders başanısina, eleştirel düşünme becerilerine ve öğrenmenin kahıliğına etkisi (Yayımlanmamış doktora tezi). Furat Üniversitesi Eğitim Bilimleri Enstitüsü, Elazığ.

Kartal, T. (2014). Sorgulamaya dayalı öğrenme-öğretme yaklaşımı, G. Ekici (Ed.). Etkinlik örnekleriyle güncel öğrenme-öğretme yaklaşımlart-I içinde (s. 472-520) (I.baskı). Ankara: Pegem Akademi Yayınclık.

Kselman, A. (2003). Supporting inquiry learning by promoting normative understanding of multivariable casuality. Journal of Research in Science Teaching, 40, 898-921.

Letina, A. (2015). Effectiveness of inquiry-based science and social studies teaching in the development of students' scientific competence. Croatian Journal of Education, 18(3), 665-696. doi: 10.15516/cje.v18i3.1735

Mentiş Taş, A. (2007). Yeni sosyal bilgiler ders kitaplarına ilişkin öğretmen görüşlerinin belirlenmesi. Selçuk Üniversitesi Sosyal Bilimler Dergisi, 17, 519-532.

Miles, M. B., ve Huberman, A. M. (1994). An expanded sourcebook: Qualitative data analysis (2th edition). Thousand Oaks, CA: SAGE Publications. 
Miles, M.B. ve Huberman, A.M. (2016). Nitel veri analizi (2.baskı). (Çev. Ed. S. Akbaba Altun ve A. Ersoy). Ankara: Pegem Akademi.

Read, M. ve Rees, M. (2006). Working in teams in early years settings. In. J. Devereux and L. Miller (Eds.). Working with children in the early years (p. 29-39) (6th edition). London: The Open University.

Şahin, H. (2004). Etkili bir sosyal bilgiler ders kitabının nitelikleri. Kazım Karabekir Ĕ̈itim Fakültesi Dergisi, 9, 365-375.

Taşkoyan, S.N. (2008). Fen ve teknoloji öğretiminde sorgulayıcı öğrenme stratejilerinin öğrencilerin sorgulayıc ögrrenme becerileri, akademik başarları ve tutumlarn üzerindeki etkisi (Yayımlanmamış yüksek lisans tezi). Dokuz Eylül Üniversitesi Eğitim Bilimleri Enstitüsü, İzmir.

Tatar N. ve Kuru, M. (2006). Fen eğitiminde araştırmaya dayalı öğrenme yaklaşımının akademik başarnya etkisi. Hacettepe Üniversitesi Eğitim Fakültesi Dergisi, 31(31), 147-158.

Yıldırım, A. ve Şimşek, H. (2008). Sosyal bilimlerde nitel araştırma yöntemleri (6. Baskı). Ankara: Seçkin Yayıncılik.

Yıldırım, A. ve Şimşek, H. (2013). Sosyal bilimlerde nitel araştırma yöntemleri (9. Baskı). Ankara: Seçkin Yayıncilik.

\section{Kaynakça Bilgisi / Citation Information}

Kaçar, T. ve Taşkıran, C. (2020). 7. sınıf sosyal bilgiler ders kitabında yer alan etkinliklerin sorgulamaya dayalı öğretime uygunluğunun değerlendirilmesi. OPUS-Uluslararası Toplum Araştırmaları Dergisi, 16(29), 1751-1779. DOI: 10.26466/opus.740607 